\title{
Using Consequence Messaging to Improve Understanding of Social Security
}

Anya Samek, Arie Kapteyn, and Andre Gray

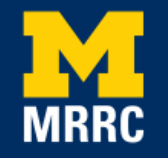

Project \#: R-UM18-09 


\title{
Using Consequence Messaging to Improve Understanding of Social Security
}

\author{
Anya Samek \\ University of Southern California \\ Arie Kapteyn \\ University of Southern California and NBER \\ Andre Gray \\ University of Southern California \\ September 2018
Michigan Retirement Research Center
University of Michigan
P.O. Box 1248
Ann Arbor, MI 48104
www.mrrc.isr.umich.edu \\ (734) 615-0422
}

\section{Acknowledgements}

The research reported herein was performed pursuant to a grant from the U.S. Social Security Administration (SSA) funded as part of the Retirement Research Consortium through the University of Michigan Retirement Research Center Award RRC08098401-10. The opinions and conclusions expressed are solely those of the author(s) and do not represent the opinions or policy of SSA or any agency of the federal government. Neither the United States government nor any agency thereof, nor any of their employees, makes any warranty, express or implied, or assumes any legal liability or responsibility for the accuracy, completeness, or usefulness of the contents of this report. Reference herein to any specific commercial product, process or service by trade name, trademark, manufacturer, or otherwise does not necessarily constitute or imply endorsement, recommendation or favoring by the United States government or any agency thereof.

\section{Regents of the University of Michigan}

Michael J. Behm, Grand Blanc; Mark J. Bernstein, Ann Arbor; Shauna Ryder Diggs, Grosse Pointe; Denise Ilitch, Bingham Farms; Andrea Fischer Newman, Ann Arbor; Andrew C. Richner, Grosse Pointe Park; Ron Weiser, Ann Arbor; Katherine E. White, Ann Arbor; Mark S. Schlissel, ex officio 


\title{
Using Consequence Messaging to Improve Understanding of Social Security
}

\begin{abstract}
In this paper, we developed and evaluated "consequence messaging," a behaviorally motivated communication strategy in which we used vignettes - video and written stories about hypothetical people - to explain the consequences of decisions. We studied two related areas where consequence messaging may improve understanding and decision-making: valuing annuities and Social Security claiming decisions. We evaluated the impact of consequence messaging by conducting a small-scale, online study on a representative sample of about 650 Americans ages 50 to 60 . We randomly assigned respondents to no vignette, a video vignette, or a written vignette. Then, we assessed the impact on understanding and decision-making through a survey. We assessed understanding by asking factual questions, and assessed decision-making by asking respondents to provide advice to a hypothetical person facing various decisions about annuities and Social Security claiming. The vignettes improved understanding and decisionmaking for both valuing annuities and Social Security claiming decisions. The effect sizes were not significantly different across written vignettes versus video vignettes. The vignettes did not have a statistically significant effect on how respondents rated the importance of concerns related to retirement.
\end{abstract}

\section{Citation}

Samek, Anya, Arie Kapteyn, and Andre Gray. 2018. "Using Consequence Messaging to Improve Understanding of Social Security," University of Michigan Retirement Research Center (MRRC) Working Paper, WP 2018-383. Ann Arbor, MI.

http://mrdrc.isr.umich.edu/publications/papers/pdf/wp383.pdf 


\section{Introduction}

Individuals are increasingly responsible for their own financial security after retirement, yet evidence shows that they have difficulty understanding complex aspects of retirement planning. The result is that they may claim Social Security earlier, or use annuities less than is optimal, leading to poor financial security in later life (Benartzi et al. 2011; Poterba et al., 2011).

Researchers have begun to document the limitations households face when making decisions affecting financial security at older ages (Lusardi and Mitchell 2007, 2011) and to evaluate interventions (e.g., financial education) that assist households with these decisions. One solution is to improve communications about complex concepts. A qualitative study found that satisfaction in retirement was related to feeling one had enough information to make a decision about Social Security claiming (Rabinovich and Samek 2018). However, the most effective content and mode of communication are still open questions.

A promising communication strategy is "consequence messaging." The premise of consequence messaging is that while expected utility theory assumes that people make decisions by evaluating all possible consequences and their probability of occurrence, decisions are actually made without fully processing this information. A benefit of consequence messaging is that it describes the outcomes of multiple decisions under different states of the world. Hence, if individuals are asked to consider the consequences of an action, this should improve their

For example, in Brown et al. (2017), people were asked to provide a lump sum amount they would be willing to pay for a permanent increase in Social Security monthly benefits, or to provide a lump sum amount they would have to be paid to accept a permanent decrease in monthly payments. Respondents provided divergent and inconsistent valuations. The implication appears to be that consumers do not understand annuities and are not able to value them. 
understanding. In recent work, Brown et al. (2017) provided individuals with a written message (a "vignette") about a hypothetical person's outcomes if he/she does or does not annuitize. The authors found that the vignette improved the valuation of annuities relative to no vignette. However, the written vignette was low-touch, and the size of the effect was moderate. Related work also explored ways of communicating information online, finding that engaging modes such as videos may lead to better understanding than written vignettes (Heinberg et al. 2014).

In this study, we contribute to the literature by developing and evaluating consequence message vignettes in two related areas where people have difficulty: valuing annuities and Social Security claiming decisions. In our vignettes, a 62-year-old man is talking to his financial advisor about his retirement budgeting plans. The financial advisor encourages the man to consider the consequences of different decisions. In the valuing annuities vignette, the man is making a decision about whether to purchase an annuity. In the Social Security claiming vignette, the man is making a decision about when to claim his Social Security benefits. In both vignettes, the financial advisor explains that outcomes depend partly on his decisions - i.e., how much money to spend down, and partly on uncertainty - i.e., the uncertainty surrounding how long the man can expect to live. The vignettes do not constitute a "pure" consequence message since the financial advisor also describes the basic features of the decision (e.g., explaining the link between claiming age and level of Social Security benefits in the Social Security vignette).

To evaluate the vignettes, we conducted a small-scale randomized controlled trial (RCT) in the Understanding America Study (UAS) with 659 participants. The UAS is a nationally representative probability-based internet panel $(\mathrm{N}=6,000)$ housed at the University of Southern California. The UAS includes member background characteristics, including the Health and 
Retirement Study instrument and cognition. ${ }^{2}$ We recruited participants ages 50 to 60 to participate in the study. As described in Section 2, we randomized participants in a 2x3 experimental design to either the Social Security or annuities scenario, and to either receive no vignette, a written vignette, or a video vignette. Participants were then asked a series of questions aimed at assessing their understanding of the concept about which they had just learned.

We found that subjects randomized to the written vignette treatment in both the annuities and the Social Security scenario were significantly better at answering true/false questions about retirement financing. Subjects randomized to the video vignette treatment also improved significantly in both scenarios. While the vignettes did seem to improve understanding of retirement financing, they had no significant effect on how respondents rated the importance of different concerns related to retirement, suggesting that the consequence messaging did not alter consequence-related beliefs. Generally, the effect sizes of the video vignettes and written vignettes were comparable.

\section{Experiment and Survey Design}

\subsection{Vignettes}

We created two vignettes about the same 62 -year-old man and his financial advisor. Each vignette (in video format) was about three minutes long. The first vignette focused on annuities, and the second vignette focused on Social Security claiming age decisions. The written scripts for the vignettes and links to the video version are provided in Appendix I. In both vignettes, a 62-year old man is meeting with his financial advisor to discuss his plans for budgeting his

\footnotetext{
${ }^{2}$ Members are recruited through Address Based Sampling. This creates an effective way to reach a representative sample; respondents without prior access to the internet receive a tablet and broadband internet. Details at https://cesr.usc.edu/data_toolbox/understanding_america_study.
} 
retirement. The goal of both vignettes is to provide information about the consequences of living longer or shorter, stress the uncertainty in one's lifespan, and explain how this impacts the money that one can spend during retirement. In the annuities vignette, the financial advisor explains that an annuity acts as insurance against uncertain life expectancy. However, the financial advisor does not actually advise purchasing an annuity. In the Social Security vignette, the financial advisor explains how monthly Social Security benefits change as a function of claiming age, and clarifies that one does not need to claim in the same year as one retires from work. However, as before, the financial advisor does not actually advise delaying claiming. Figure 1 provides screenshots of the video vignettes.

Figure 1: Screenshots of video vignettes
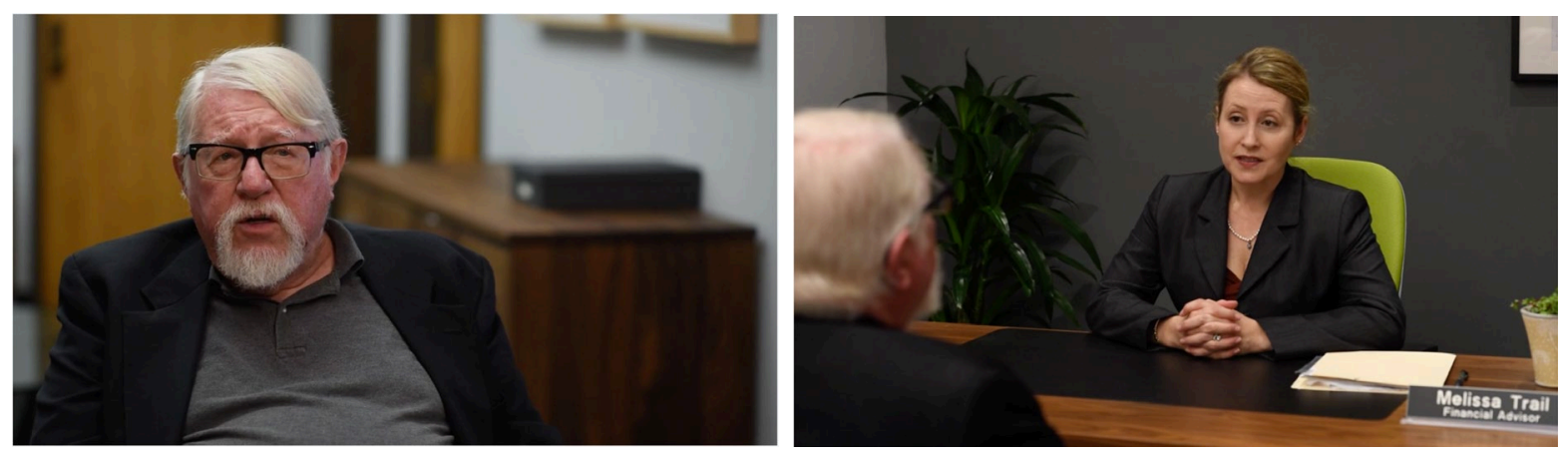

\subsection{Experiment Design}

Our experimental design is presented in Table 1. We recruited 659 UAS panel members ages 50 to 60 years old with the goal of randomizing about 110 to each of the six treatment cells. The randomization was done by the computer program when respondents logged in to participate. Half of the sample was exposed to the annuities condition and half of the sample was exposed to the Social Security condition. One-third of the sample was asked to watch the threeminute video vignette (about annuities or Social Security, depending on condition), one-third 
was asked to read a transcript of the vignette (again, about annuities or Social Security, depending on condition) and one-third did not receive any intervention.

Table 1: experimental design

\begin{tabular}{|l|c|c|c|}
\hline & Control & Written Vignette & Video Vignette \\
\hline Annuities & 108 & 110 & 100 \\
\hline Social Security & 105 & 113 & 123 \\
\hline Total & 213 & 223 & 223 \\
\hline
\end{tabular}

\subsection{Survey questions and hypotheses}

After respondents participated in the intervention (if any) all respondents received a three to five minute follow-up survey. The survey questions are available in Appendix II. First, respondents were given two scenarios about the man from the video (in random order) and asked to give advice to the man about how much annuity to purchase or when to claim. ${ }^{3}$ The "longlife" scenario described the man as being in relatively good health and expecting to live a longer life (to about age 85) while the "short-life" scenario described the man as being in relatively poor health and expecting to live a shorter life (to about age 70). Respondents with a better understanding are expected to advise a later claiming age or larger annuity purchase amount in the long-life scenario versus the short-life scenario. Hence, if the consequence message is effective at improving understanding, we would expect respondents randomized to the consequence treatments to be more likely to give directionally accurate responses than respondents randomized to the control group.

Second, respondents received four true/false questions (in random order) about annuities or Social Security. If the consequence message is effective at improving understanding, we would

\footnotetext{
${ }^{3}$ We additionally randomized the name of the man in the scenario - which was either John or Bill.
} 
expect respondents randomized to the consequence treatments to answer more of the true/false questions correctly than respondents randomized to the control group.

Third, we asked respondents how much importance they place on several concerns that people may have about retirement (in random order). Again, the concerns were related to annuities or Social Security, depending on condition. Three of the concerns were related to considering consequences and two were not. If the consequence message helps people consider the consequences of different outcomes, we expect respondents randomized to the consequence treatments to place a higher importance on the consequence-related concerns versus respondents randomized to the control group.

The remaining questions asked about preferences for mode of receiving communication about annuities or Social Security, expectations about one's own claim or annuitization decisions, and (for those in the consequence treatments) feedback about the vignette.

\section{Results}

Table A1 in Appendix III provides summary statistics of our sample, showing balance on observable characteristics by treatment. This suggests that our randomization "worked" as intended. A small number of respondents (one respondent in the written condition and 14 respondents in the video condition) report in a question immediately after the vignette that they were not able to read/view the entire vignette. These respondents are dropped from the remainder of the analysis. We next evaluate the impact of the consequence treatments on each of the survey components.

Survey Part 1: Overall, in the Social Security condition, 279 of 341 (81.9\%) of respondents gave a directionally accurate response and in the annuities condition 225 of 318 $(70.8 \%)$ of respondents gave a directionally accurate response. Table 2 summarizes the 
proportion of directionally accurate responses by treatment. The proportion of directionally accurate responses is higher in treatment relative to control by about 2 percentage points in the Social Security scenario. In the annuities scenario, the written vignette shows a 9 percentage points improvement, compared to about 3.5 percentage points for the video vignette. Although the number of directionally correct responses is larger for the treatment groups (particularly for the written vignette treatments in the annuities scenario), the differences are not statistically significant.

Table 2: Directionally accurate responses by treatment

\begin{tabular}{|l|c|c|c|}
\hline & Control & Written Vignette & Video Vignette \\
\hline Annuities & $66.7 \%$ & $75.5 \%$ & $70.0 \%$ \\
\hline Social Security & $80.1 \%$ & $82.3 \%$ & $82.1 \%$ \\
\hline
\end{tabular}

Survey Part 2: Overall, the average percentage of correct true/false responses in the Annuities scenario was $86.9 \%($ S.D. $=21.0)$ and the average percentage of correct true/false responses in the Social Security scenario was $88.1 \%$ (S.D.=22.2). Table 3 summarizes the percent correct by treatment. Relative to the control group, the vignettes show a higher percent correct by about 10 percentage points for the annuities scenario and 15 percentage points for the Social Security scenario. We find that in the annuities scenario, both written and video vignettes showed statistically significantly higher percentages of correct answers versus control at the $1 \%$ level ( $p<0.001$ for both vignettes). In the Social Security scenario, the written and video vignettes also showed statistically significantly higher percentages of correct answers versus control at the $1 \%$ level $(\mathrm{p}<.001$ for both vignettes $)$. 
Table 3: Percentage of correct true/false questions

\begin{tabular}{|l|c|c|c|}
\hline & Control & Written Vignette & Video Vignette \\
\hline Annuities & $80.1 \%$ & $90.7 \%$ & $90.25 \%$ \\
& $(22.35)$ & $(18.19)$ & $(20.69)$ \\
\hline Social Security & $77.6 \%$ & $93.4 \%$ & $92.28 \%$ \\
& $(25.93)$ & $(16.71)$ & $(20.28)$ \\
\hline
\end{tabular}

Survey Part 3: The average amount of importance placed on the three consequencerelated issues 4 was 3.59 (S.D.=0.87) on a five-point Likert scale, while the average amount of importance placed on the two issues unrelated to consequences 5 was $3.78($ S.D. $=0.91)$ on the same scale. Table 4 provides the breakdown for these numbers by treatment. When looking at annuities and Social Security separately, we only find a statistically significant treatment effect for the written treatment of the annuities scenario in the "No-Consequence case" $(p=0.04)$. When combining the annuities and Social Security scenarios we find only a small, marginally statistically significant difference between written and control treatments in the "NoConsequence" case $(\mathrm{p}=0.07)$.

\footnotetext{
${ }^{4}$ For annuities, these are answers on a five-point scale from "Not at all important" to "Very Important" on the importance of (1) "The risk of not getting to spend most of your money in your lifetime"; (2) "The risk of running out of money in your lifetime"; (3) Uncertainty about how long you will live." For Social Security the items are (1) "The risk of claiming Social Security too late and not getting to enjoy the full benefits in your lifetime"; (2) "Uncertainty about how long you will live"; (3) "The risk of claiming Social Security too early and getting a lower monthly payment during your lifetime." See Appendix II.

${ }^{5}$ For both annuities and Social Security, these are answers on a five-point scale from "Not at all important" to "Very Important" on the importance of (1) "Whether you have enough money saved up for retirement"; (2) "Leaving money for your children or other dependents." See Appendix II
} 
Table 4: Importance of issues related to retirement planning

\begin{tabular}{|l|c|c|c|}
\hline & Control & Written Vignette & Video Vignette \\
\hline & \multicolumn{3}{|c|}{ Panel A: Consequence Related } \\
\hline Annuities & 3.52 & 3.50 & 3.69 \\
& $(0.934)$ & $(0.890)$ & $(0.776)$ \\
\hline Social Security & 3.67 & 3.49 & 3.71 \\
& $(0.871)$ & $(0.846)$ & $(0.863)$ \\
\hline & \multicolumn{3}{|c|}{ Panel B: Not Consequence Related } \\
\hline Annuities & 3.87 & 3.62 & 3.89 \\
& $(0.859)$ & $(0.984)$ & $(0.832)$ \\
\hline Social Security & 3.82 & 3.74 & 3.79 \\
& $(0.957)$ & $(0.894)$ & $(0.887)$ \\
\hline
\end{tabular}

We next conduct regressions (see Table A2 in Appendix III) explaining the different outcome variables, with dummy variables for each treatment. We include the same controls that are available in Table A1. We find that, for both annuities and Social Security, the treatment effects on the percent of correct true/false responses remain statistically significant at the $1 \%$ level when controls are included.

Survey Part 4: Finally, we describe respondent preferences for receiving communications. The most commonly selected preference for receiving communications was receiving information in the mail (37.78\% of respondents), followed by reading an article online $(26.25 \%$ of respondents), and watching a video online (24.28\% of respondents). Given that we are in the "digital age," it may be surprising that most respondents preferred to receive information in the mail. This preference could be generational — our respondents were ages 50 to 60 .

\section{Discussion and Conclusion}

We conducted a study to understand the impact of "consequence messaging" on understanding of and decisions related to annuitizing and Social Security claiming. We evaluated the impact of "consequence messaging" by fielding a survey with about 650 respondents of the 
probability-based Understanding America Study. We randomized respondents to one of six conditions to evaluate the impact of written or video vignettes, versus no vignette (control).

As shown in Tables 2 and 3 (and Tables A2 and A3 in Appendix III), we found that compared to the control groups, the vignettes led to more correct responses to the questions that gauged understanding. The effect sizes did not differ across the type of vignette. The size of the sample used in this experiment is moderate. It is possible that for larger samples some of the other effects will be statistically significant.

Our study leaves several questions open for future work. From a theoretical perspective, research should try to better understand what it is about consequence messaging that makes it effective. This work should include considering why consequence messaging works for conveying factual information, but was not particularly effective at increasing concerns about consequences. From a practical perspective, research should explore whether the preference for mail communication we observed is generational, and whether younger respondents might prefer other methods, e.g., online. Finally, future work could address other types of consequence messaging, for example, addressing risk perception in a broader range of settings. 


\section{References}

Benartzi, Shlomo, Alessandro Previtero, and Richard H. Thaler. 2011. “Annuitization puzzles.” The Journal of Economic Perspectives 25, no. 4, 143-164.

Brown, Jeffrey R., Arie Kapteyn, Erzo F.P. Luttmer, and Olivia S. Mitchell. 2017. “Cognitive Constraints on Valuing Annuities.” Journal of the European Economic Association 15, no. 2: 429-462.

Heinberg, Aileen, Angela A. Hung, Arie Kapteyn, Annamaria Lusardi, Anya Savikhin Samek, and Joanne Yoong. 2014. "Five steps to planning success. Experimental evidence from US households.” No. w20203. National Bureau of Economic Research.

Lusardi, Annamaria, and Olivia S. Mitchell. 2007. "Baby boomer retirement security: The roles of planning, financial literacy, and housing wealth." Journal of Monetary Economics 54, no. 1: 205-224.

Lusardi, Annamaria, and Olivia S. Mitchell. 2011. "Financial literacy and planning: Implications for retirement wellbeing." No. w17078. National Bureau of Economic Research.

Poterba, James M., Steven F. Venti, and David A. Wise. 2011. "Were They Prepared for Retirement? Financial Status at Advanced Ages in the HRS and AHEAD Cohorts." In Investigations in the Economics of Aging, pp. 21-69. University of Chicago Press.

Rabinovich, Lila, and Anya Samek. 2018. “'No Regrets': Qualitative Evidence on Early Claiming of Social Security Retirement.” Journal of Aging Studies 46: 17-23. 


\section{Appendix I}

\section{Script A1: Annuities written script}

(Link A1: Annuities Vignette: https://www.youtube.com/watch?v=-AbXiHpXewU )

Bill is talking to his financial advisor in an office about how to spend down his savings in retirement.

Financial advisor: Good to see you today. How can I help?

Bill: Well, I've just retired recently and started claiming my Social Security benefits, and now I need to figure out how to budget my retirement savings.

Financial advisor: As a financial advisor, I can help you with that. It's a tradeoff. You can decide to spend down your retirement savings relatively quickly. In that case, you'll be more likely to enjoy your money while you're alive. But you also run the risk of having to cut back on your spending.

Bill: So, if I start spending relatively quickly and take all those vacation trips I've been wanting to, then I run the risk of not having the money when I need it?

Financial advisor: That's right. You could also decide to spend down your savings relatively slowly. In that case, you'll be less likely to run out of money. But then you run the risk of not getting to enjoy all of your money while you're alive.

Financial advisor: According to data from Social Security calculators, a man turning age 62 today can expect to live, on average, until he's 82 years old. That's about 20 years.

Financial advisor: The issue is, of course, we can't know now whether you'll live until 82 or beyond - these are just averages.

Financial advisor: For example, if you think you'll only live until you're 80, you could spend each more money each month, but then you would have to cut back on your spending if you live past 80 .

Bill: But if I don't live to 80, I may not be able to enjoy all my savings.

Financial advisor: Or if you think you'll live until you're 90, you should spend less each month, but again you'll still have to cut back on your spending if you live past 90. 
Bill: These are difficult decisions.

Financial advisor: The good news is that there are financial products that can help you reduce the risk of running out of money during your lifetime. One thing I can suggest is an annuity.

Bill: Ugh, annuities! I've heard that annuities are so complicated, and if you die early, basically you're throwing your money away.

Financial advisor: That's not entirely true. Annuities are like insurance against outliving your money. You pay a premium up front, but then you're guaranteed a monthly payment until you die. That means if you live longer, you also get to spend more money.

Bill: That's not such a bad deal ... so I make a payment now, and in return, I get a stream of income for life?

Financial advisor: Research shows that many people should consider annuitizing, but very few actually do. That's probably because of the misinformation floating around about annuities.

Bill: But if I buy an annuity, and I don't live as long as I expected, I still run the risk of not having a chance to spend most of my money before I die.

Financial advisor: That's true. But you do not have to annuitize all of your savings. You could annuitize half or even a quarter.

Bill: Ah, that's interesting. I'll think about it.

Financial advisor: Great, let's talk again soon. 


\section{Script A2: Social Security written script}

(Link A2: Social Security Vignette: https://www.youtube.com/watch?v=pyOi27efL4Q )

Bill is talking to his financial advisor in an office about when to claim Social Security.

Financial advisor: Good to see you today. How can I help?

Bill: Well, I've been thinking about retiring soon, and I'm wondering what's the best time to actually claim my Social Security benefits.

Financial advisor: As a financial advisor, I can help you with that. Your retirement benefits depend on the age when you begin claiming. It's a tradeoff: You can decide to claim earlier. In that case, you would have lower monthly benefits, but you'd also get to enjoy these benefits for a longer period.

Bill: So if I claim sooner, I get less money per month?

Financial advisor: That's right. You can also decide to claim later. In that case, you would get higher monthly benefits, but you'd get to enjoy these benefits for a shorter period.

Bill: So I get more money per month, but I don't get to enjoy it for as long a time. These are hard decisions.

Financial advisor: According to data from Social Security calculators, a man turning age 62 today can expect to live, on average, until he is 82 years old. That's about 20 years!

Financial advisor: The issue is, of course, we can't know now whether you'll live until 82 or beyond - these are just averages.

Financial advisor: For example, if you think you'll only live until you are 80, you could claim sooner so you could enjoy these benefits for a longer period of time.

Bill: But the monthly payments will be lower.

Financial advisor: That's right. Or if you think you'll live until you are 90, you may want to delay claiming so you could get higher monthly payments.

Bill: So, the benefits will be higher, but I don't get to collect them for as long. These are hard decisions. 
Financial advisor: Let me tell you more. You can claim any time after age 62. But for every year you delay, your benefits are increased by 5 to $8 \%$ each year.

In this example, suppose you want to claim at age 62 - the earliest you could claim - your monthly benefit would be $\$ 750$ a month. Or if you delay until 63, your benefits go up to $\$ 800$ a month. Your benefits continue to increase each year until you get to your maximum monthly benefit of $\$ 1,320$ at age 70 . You can still claim after that, but your benefits won't increase.

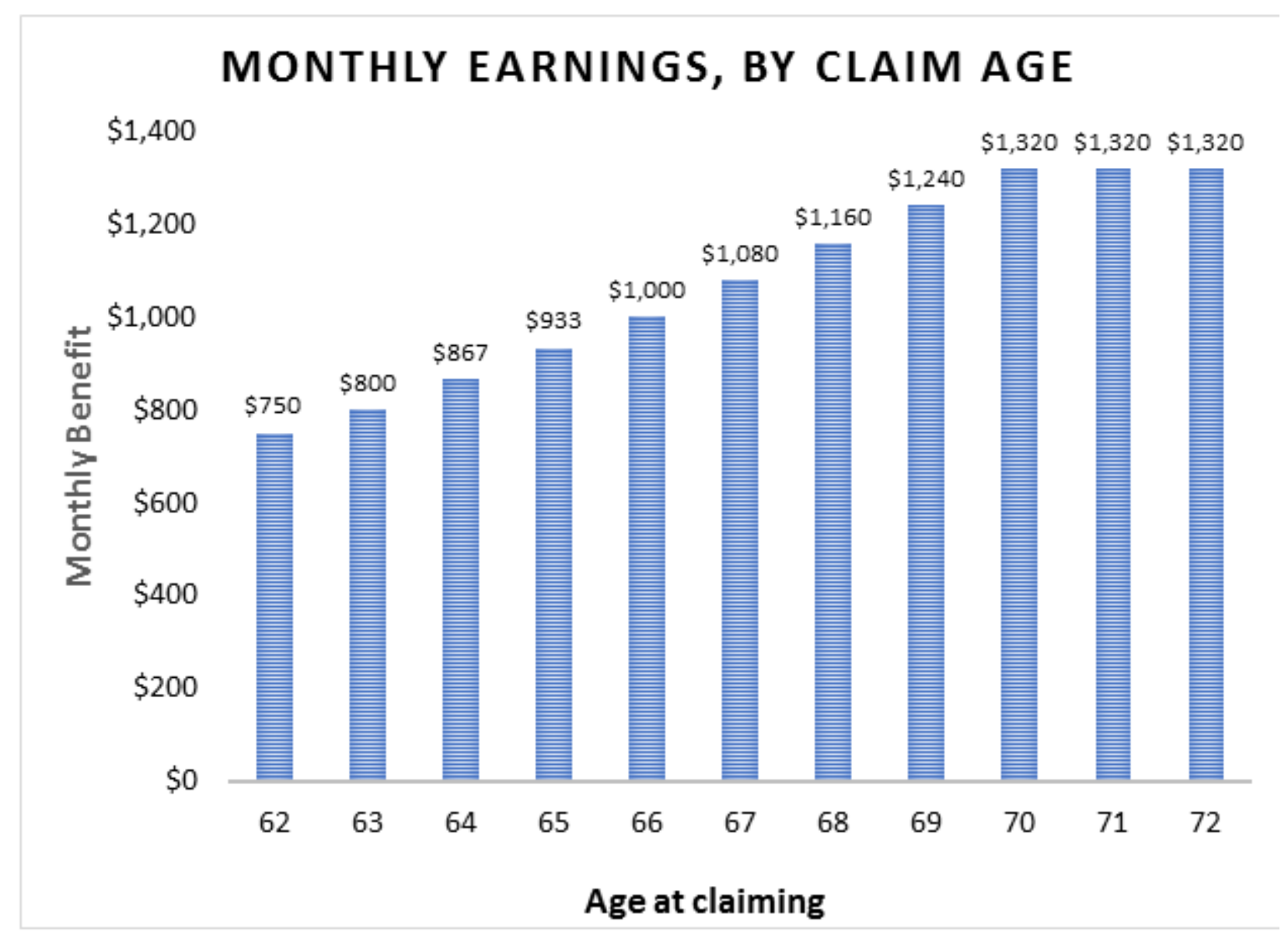

This is just an example based on retirement planning calculators available on ssa.gov and your earnings may differ. View your Social Security statement or visit ssa.gov to learn about your own benefits.

Bill: I understand that if I delay claiming I can get more money per month, but what if I just want to retire now. I'm so tired of working, and I just want to enjoy my life.

Financial advisor: A little known fact is you do not have to start claiming the same year you retire. You can retire, live off your retirement savings, and claim later if you want to. 
Financial advisor: For most people who have any retirement savings at all, delaying claiming could make sense for them because the amount of interest you earn on your retirement savings is lower than the amount of interest you get from Social Security just by postponing claiming.

Bill: Huh, I didn't know that. I'll think about it.

Financial advisor: Great, let's talk again soon. 


\section{Appendix II}

\section{Survey A1: Annuities Survey}

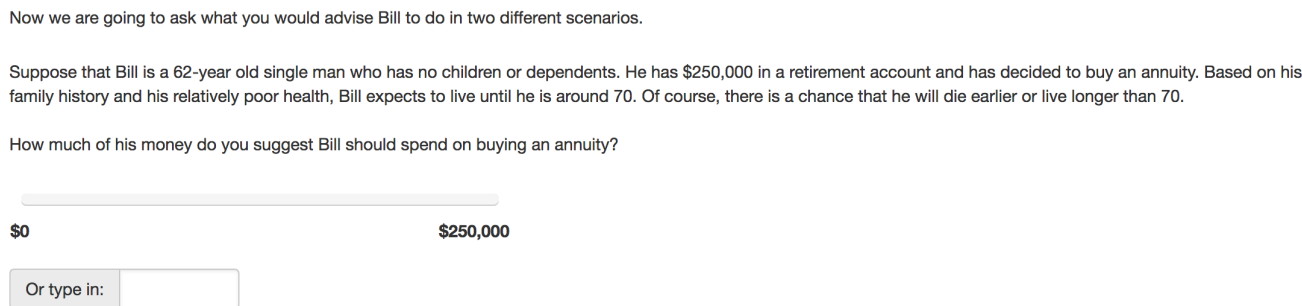

\$o

$\$ 250,000$

Or type in:

Do you think the following statements are true or false?

\begin{tabular}{|l|l|l|}
\hline & True \\
\hline You can buy an annuity with your retirement savings. \\
\hline An annuity is a financial product that pays a lump sum when you die. \\
\hline $\begin{array}{l}\text { An annuity is a financial product that is like insurance against outliving your money } \\
\text { in your lifetime. }\end{array}$ \\
\hline If you purchase an annuity, you can do so with just part and not all of your savings.
\end{tabular}

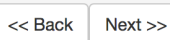

Please indicate how important you consider each of the below when planning for retirement:

\begin{tabular}{|c|c|c|c|c|c|c|}
\hline & $\begin{array}{l}\text { Not at all } \\
\text { Important }\end{array}$ & $\begin{array}{l}\text { Slightly } \\
\text { Important }\end{array}$ & Important & $\begin{array}{c}\text { Fairly } \\
\text { Important }\end{array}$ & $\begin{array}{c}\text { Very } \\
\text { Important }\end{array}$ & No Opinion \\
\hline $\begin{array}{l}\text { The risk of not getting to spend most of your money in your } \\
\text { lifetime. }\end{array}$ & 0 & 0 & 0 & 0 & 0 & 0 \\
\hline Whether you have enough money saved up for retirement. & 0 & 0 & 0 & 0 & 0 & 0 \\
\hline The risk of running out of money in your lifetime. & 0 & 0 & 0 & 0 & 0 & 0 \\
\hline Leaving money for your children or other dependents. & 0 & 0 & 0 & 0 & 0 & 0 \\
\hline Uncertainty about how long you will live. & 0 & 0 & 0 & 0 & 0 & 0 \\
\hline
\end{tabular}


Suppose you want to learn more about annuities and have an option from one of the below. Which would you prefer to do?

Watch a video online (on your computer, phone or tablet)

Receive information in the mai

Read an article online (on your computer, phone or tablet)

None of the above

$\ll$ Back Next $\gg$

How likely are you to purchase an annuity in the future?

Extremely Unlikely

Unlikely

Neutral

Likely

Extremely Likely

You just read a story about annuities.

Can you comment on what you found most helpful about the story?

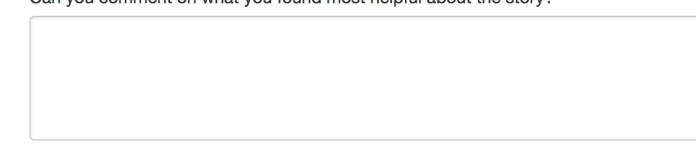

« Back Next $\gg>$

Could you tell us how interesting or uninteresting you found the questions in this interview?
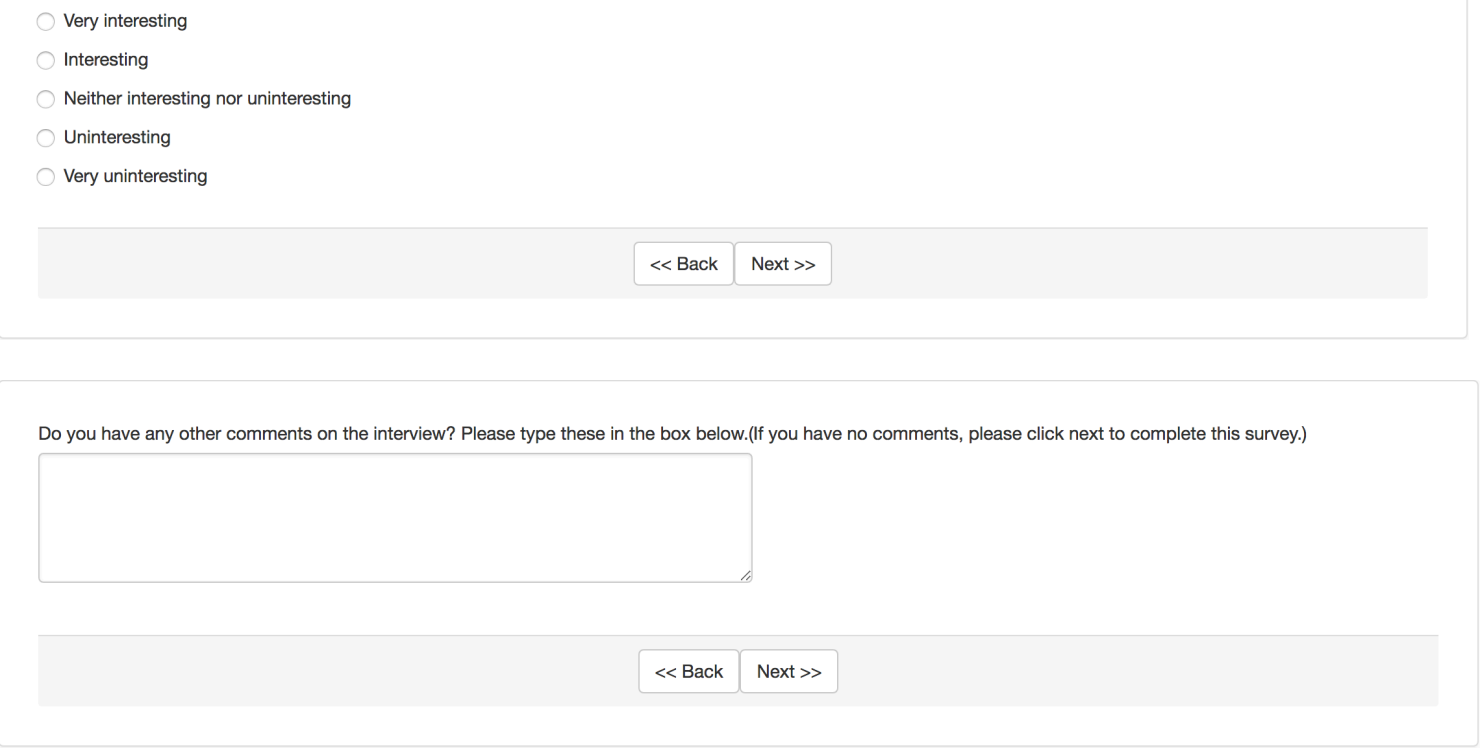


\section{Survey A2: Social Security Survey}

\section{Now we are going to ask what you would advise John to do in two different scenarios}

Suppose that John is a 62-year old single man who has no children or dependents. Based on his family history and his relatively poor health, John expects to live until he is around 70. Of course, there is a chance that he will die earlier or live longer than 70. Regardless of when he claims Social Security, John has enough retirement savings to live another 10 years before running out of money.

At what age do you suggest John should claim Social Security?

62

64

66

68

70

Now suppose that based on his family history and his relatively good health, John expects to live at least until he is 85 . Of course, there is a chance that he will die earlier or live longer than 85 . Regardless of when he claims Social Security, as before, John has enough retirement savings to live another 10 years before running out of money.

At what age do you suggest John should claim Social Security?

$\begin{array}{llllll}62 & 64 & 66 & 68 & 70\end{array}$

$$
\text { « Back Next } \gg
$$

Do you think the following statements are true or false?

\begin{tabular}{|l|l|l|}
\hline & True & False \\
\hline $\begin{array}{l}\text { Claiming Social Security earlier results in a lower monthly payment for a longer } \\
\text { period. }\end{array}$ & \\
\hline You have to claim Social Security as soon as you stop working completely. & \\
\hline $\begin{array}{l}\text { Claiming Social Security later results in a higher monthly payment for a shorter } \\
\text { period. }\end{array}$ & \\
\hline You can retire, live off of your retirement savings, and claim Social Security later. & \\
\hline
\end{tabular}

« Back Next $\gg$

Please indicate how important you consider each of the below when planning for retirement:

\begin{tabular}{|c|c|c|c|c|c|c|}
\hline & $\begin{array}{l}\text { Not at all } \\
\text { Important }\end{array}$ & $\begin{array}{c}\text { Slightly } \\
\text { Important }\end{array}$ & Important & $\begin{array}{c}\text { Fairly } \\
\text { Important }\end{array}$ & $\begin{array}{c}\text { Very } \\
\text { Important }\end{array}$ & No Opinion \\
\hline $\begin{array}{l}\text { The risk of claiming Social Security too late and not getting to } \\
\text { enjoy the full benefits in your lifetime. }\end{array}$ & 0 & 0 & 0 & 0 & 0 & 0 \\
\hline Uncertainty about how long you will live. & 0 & 0 & 0 & 0 & 0 & $\bigcirc$ \\
\hline Leaving money for your children or other dependents. & 0 & 0 & 0 & 0 & 0 & 0 \\
\hline Whether you have enough money saved up for retirement. & 0 & 0 & 0 & 0 & 0 & 0 \\
\hline $\begin{array}{l}\text { The risk of claiming Social Security too early and getting a lower } \\
\text { monthly payment during your lifetime. }\end{array}$ & 0 & 0 & 0 & 0 & 0 & 0 \\
\hline
\end{tabular}

«<Back Next 》 
Suppose you want to learn more about Social Security and have an option from one of the below. Which would you prefer to do?

Receive information in the mai

Watch a video online (on your computer, phone or tablet)

Read an article online (on your computer, phone or tablet)

None of the above

\section{« Back Next 》}

Do you expect to be eligible for Social Security in the future?

Yes

No

Don't know

At what age would you choose to start claiming Social Security benefits?

Age in Years:

You just watched a video about Social Security benefits.

Can you comment on what you found most helpful about the video?

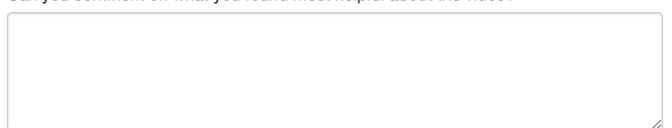

« Back Next >

Could you tell us how interesting or uninteresting you found the questions in this interview?

Very interesting

Interesting

Neither interesting nor uninteresting

Uninteresting

Very uninteresting

« Back Next »

Do you have any other comments on the interview? Please type these in the box below.(ff you have no comments, please click next to complete this survey.) 


\section{Appendix III}

Table A1: Balance Table

\begin{tabular}{|c|c|c|c|c|c|c|c|}
\hline & $\begin{array}{c}\text { Annuities } \\
\text { control }\end{array}$ & $\begin{array}{l}2 \text { Annuities } \\
\text { written }\end{array}$ & $\begin{array}{c}\text { Annuities } \\
\text { video }\end{array}$ & $\begin{array}{c}\text { Social Sec } \\
\text { control }\end{array}$ & $\begin{array}{c}\text { Social Sec } \\
\text { written }\end{array}$ & $\begin{array}{l}\text { Social Sec } \\
\text { video }\end{array}$ & $\overline{\text { F-Test }}$ \\
\hline Age & $\begin{array}{c}55.593 \\
(0.301)\end{array}$ & $\begin{array}{c}55.083 \\
(0.296)\end{array}$ & $\begin{array}{l}55.520 \\
(0.314)\end{array}$ & $\begin{array}{c}55.162 \\
(0.320)\end{array}$ & $\begin{array}{r}55.841 \\
(0.261)\end{array}$ & $\begin{array}{c}55.285 \\
(0.278)\end{array}$ & 0.438 \\
\hline Gender - Male & $\begin{array}{c}0.407 \\
(0.048)\end{array}$ & $\begin{array}{c}0.473 \\
(0.048)\end{array}$ & $\begin{array}{c}0.530 \\
(0.050)\end{array}$ & $\begin{array}{c}0.390 \\
(0.048)\end{array}$ & $\begin{array}{c}0.478 \\
(0.047)\end{array}$ & $\begin{array}{c}0.488 \\
(0.045)\end{array}$ & 0.326 \\
\hline White & $\begin{array}{c}0.889 \\
(0.030)\end{array}$ & $\begin{array}{c}0.909 \\
(0.028)\end{array}$ & $\begin{array}{c}0.830 \\
(0.038)\end{array}$ & $\begin{array}{c}0.800 \\
(0.039)\end{array}$ & $\begin{array}{c}0.858 \\
(0.033)\end{array}$ & $\begin{array}{c}0.884 \\
(0.029)\end{array}$ & 0.185 \\
\hline Black & $\begin{array}{c}0.083 \\
(0.027)\end{array}$ & $\begin{array}{c}0.027 \\
(0.016)\end{array}$ & $\begin{array}{c}0.120 \\
(0.033)\end{array}$ & $\begin{array}{c}0.143 \\
(0.034)\end{array}$ & $\begin{array}{c}0.124 \\
(0.031)\end{array}$ & $\begin{array}{c}0.091 \\
(0.026)\end{array}$ & 0.064 \\
\hline Asian & $\begin{array}{c}0.028 \\
(0.016)\end{array}$ & $\begin{array}{c}0.027 \\
(0.016)\end{array}$ & $\begin{array}{c}0.070 \\
(0.026)\end{array}$ & $\begin{array}{c}0.076 \\
(0.026)\end{array}$ & $\begin{array}{c}0.027 \\
(0.015)\end{array}$ & $\begin{array}{c}0.033 \\
(0.016)\end{array}$ & 0.226 \\
\hline Amer. Indian/Alaska & $\begin{array}{c}0.037 \\
(0.018)\end{array}$ & $\begin{array}{c}0.082 \\
(0.026)\end{array}$ & $\begin{array}{c}0.010 \\
(0.010)\end{array}$ & $\begin{array}{c}0.067 \\
(0.024)\end{array}$ & $\begin{array}{c}0.080 \\
(0.026)\end{array}$ & $\begin{array}{c}0.008 \\
(0.008)\end{array}$ & 0.016 \\
\hline Mixed Race & $\begin{array}{c}0.056 \\
(0.022)\end{array}$ & $\begin{array}{c}0.045 \\
(0.020)\end{array}$ & $\begin{array}{c}0.040 \\
(0.020)\end{array}$ & $\begin{array}{c}0.086 \\
(0.027)\end{array}$ & $\begin{array}{c}0.080 \\
(0.026)\end{array}$ & $\begin{array}{c}0.016 \\
(0.011)\end{array}$ & 0.180 \\
\hline Span./Hisp/Latino & $\begin{array}{c}0.102 \\
(0.029)\end{array}$ & $\begin{array}{c}0.073 \\
(0.025)\end{array}$ & $\begin{array}{c}0.080 \\
(0.027)\end{array}$ & $\begin{array}{c}0.086 \\
(0.027)\end{array}$ & $\begin{array}{c}0.088 \\
(0.027)\end{array}$ & $\begin{array}{c}0.089 \\
(0.026)\end{array}$ & 0.985 \\
\hline$<30,000$ & $\begin{array}{c}0.296 \\
(0.044)\end{array}$ & $\begin{array}{c}0.255 \\
(0.042)\end{array}$ & $\begin{array}{c}0.200 \\
(0.040)\end{array}$ & $\begin{array}{c}0.257 \\
(0.043)\end{array}$ & $\begin{array}{c}0.292 \\
(0.043)\end{array}$ & $\begin{array}{c}0.179 \\
(0.035)\end{array}$ & 0.221 \\
\hline $30,000-59,000$ & $\begin{array}{c}0.231 \\
(0.041)\end{array}$ & $\begin{array}{c}0.209 \\
(0.039)\end{array}$ & $\begin{array}{c}0.300 \\
(0.046)\end{array}$ & $\begin{array}{c}0.248 \\
(0.042)\end{array}$ & $\begin{array}{c}0.345 \\
(0.045)\end{array}$ & $\begin{array}{c}0.333 \\
(0.043)\end{array}$ & 0.114 \\
\hline $60,000-99,999$ & $\begin{array}{c}0.204 \\
(0.039)\end{array}$ & $\begin{array}{c}0.227 \\
(0.040)\end{array}$ & $\begin{array}{c}0.230 \\
(0.042)\end{array}$ & $\begin{array}{c}0.229 \\
(0.041)\end{array}$ & $\begin{array}{c}0.150 \\
(0.034)\end{array}$ & $\begin{array}{c}0.260 \\
(0.040)\end{array}$ & 0.461 \\
\hline $100,000+$ & $\begin{array}{c}0.269 \\
(0.043)\end{array}$ & $\begin{array}{c}0.309 \\
(0.044)\end{array}$ & $\begin{array}{c}0.270 \\
(0.045)\end{array}$ & $\begin{array}{c}0.267 \\
(0.043)\end{array}$ & $\begin{array}{c}0.212 \\
(0.039)\end{array}$ & $\begin{array}{c}0.228 \\
(0.038)\end{array}$ & 0.626 \\
\hline High School or Less & $\begin{array}{c}0.269 \\
(0.043)\end{array}$ & $\begin{array}{c}0.245 \\
(0.041)\end{array}$ & $\begin{array}{c}0.290 \\
(0.046)\end{array}$ & $\begin{array}{c}0.295 \\
(0.045)\end{array}$ & $\begin{array}{c}0.265 \\
(0.042)\end{array}$ & $\begin{array}{c}0.220 \\
(0.037)\end{array}$ & 0.803 \\
\hline Some College & $\begin{array}{c}0.241 \\
(0.041)\end{array}$ & $\begin{array}{c}0.273 \\
(0.043)\end{array}$ & $\begin{array}{c}0.130 \\
(0.034)\end{array}$ & $\begin{array}{c}0.181 \\
(0.038)\end{array}$ & $\begin{array}{c}0.283 \\
(0.043)\end{array}$ & $\begin{array}{c}0.301 \\
(0.042)\end{array}$ & 0.023 \\
\hline Bachelor & $\begin{array}{c}0.222 \\
(0.040)\end{array}$ & $\begin{array}{c}0.255 \\
(0.042)\end{array}$ & $\begin{array}{c}0.210 \\
(0.041)\end{array}$ & $\begin{array}{c}0.238 \\
(0.042)\end{array}$ & $\begin{array}{c}0.124 \\
(0.031)\end{array}$ & $\begin{array}{c}0.171 \\
(0.034)\end{array}$ & 0.152 \\
\hline Assc. College Degree & $\begin{array}{c}0.130 \\
(0.032)\end{array}$ & $\begin{array}{c}0.100 \\
(0.029)\end{array}$ & $\begin{array}{c}0.290 \\
(0.046)\end{array}$ & $\begin{array}{c}0.181 \\
(0.038)\end{array}$ & $\begin{array}{c}0.221 \\
(0.039)\end{array}$ & $\begin{array}{c}0.195 \\
(0.036)\end{array}$ & 0.007 \\
\hline Master/Prof/Dr & $\begin{array}{c}0.139 \\
(0.033)\end{array}$ & $\begin{array}{c}0.127 \\
(0.032)\end{array}$ & $\begin{array}{c}0.080 \\
(0.027)\end{array}$ & $\begin{array}{c}0.105 \\
(0.030)\end{array}$ & $\begin{array}{c}0.106 \\
(0.029)\end{array}$ & $\begin{array}{c}0.114 \\
(0.029)\end{array}$ & 0.827 \\
\hline
\end{tabular}

Note: This table presents average proportions for demographic variables by treatment. The F-test column shows p-values for tests of equivalence among treatments. Signi cant values are adjusted with a bonferroni correction $* \mathrm{p}<0.006, * * \mathrm{p}<0.003, * * * \mathrm{p}<0.0006$ 
Table A2: annuity results

\begin{tabular}{lcccc}
\hline & $(1)$ & $(2)$ & $(3)$ & $(4)$ \\
& $\begin{array}{c}\text { Direction } \\
\text { Accurate }\end{array}$ & Percent Correct & $\begin{array}{c}\text { Avg. Likert } \\
\text { Conseq }\end{array}$ & $\begin{array}{c}\text { Avg. Likert No } \\
\text { Conseq }\end{array}$ \\
\hline Written Vignette & 0.08 & $9.78^{* * *}$ & 0.03 & $-0.23^{*}$ \\
& $(0.06)$ & $(2.81)$ & $(0.12)$ & $(0.12)$ \\
Video Vignette & 0.02 & $9.19^{* * *}$ & 0.15 & 0.03 \\
& $(0.07)$ & $(2.93)$ & $(0.13)$ & $(0.13)$ \\
Constant & $1.46^{* * *}$ & $95.28^{* * *}$ & $2.80^{* * *}$ & $2.72^{* * *}$ \\
& $(0.49)$ & $(21.36)$ & $(0.93)$ & $(0.95)$ \\
\hline R2 & 0.03 & 0.12 & 0.05 & 0.08 \\
$\mathrm{~N}$ & 317.00 & 317.00 & 312.00 & 311.00 \\
\hline
\end{tabular}

This table presents results from OlS regressions of each outcome variable on treatments for subjects assigned to the Annuities scenario. All regressions control for age, gender, race, household income and education. $* \mathrm{p}<0.10,{ }^{* *} \mathrm{p}<0.05,{ }^{* * *} \mathrm{p}<0.010$ 


\section{Table A3: Social Security results}

\begin{tabular}{lcccc}
\hline & $\begin{array}{c}(1) \\
\text { Direction } \\
\text { Accurate }\end{array}$ & $\begin{array}{c}(2) \\
\text { Percent Correct }\end{array}$ & $\begin{array}{c}(3) \\
\text { Avg. Likert } \\
\text { Conseq }\end{array}$ & $\begin{array}{c}(4) \\
\text { Avg. Likert No } \\
\text { Conseq }\end{array}$ \\
\hline Written Vignette & 0.02 & $16.07^{* * *}$ & -0.19 & -0.02 \\
& $(0.05)$ & $(2.93)$ & $(0.12)$ & $(0.13)$ \\
Video Vignette & 0.01 & $14.68^{* * *}$ & 0.03 & -0.02 \\
& $(0.05)$ & $(2.89)$ & $(0.12)$ & $(0.13)$ \\
Constant & $1.03^{* * *}$ & $54.13^{* *}$ & $4.27^{* * *}$ & $4.72^{* * *}$ \\
& $(0.40)$ & $(21.47)$ & $(0.89)$ & $(0.94)$ \\
\hline $\mathrm{R} 2$ & 0.04 & 0.16 & 0.05 & 0.05 \\
$\mathrm{~N}$ & 339.00 & 339.00 & 334.00 & 333.00 \\
\hline
\end{tabular}

This table presents results from OlS regressions of each outcome variable on treatments for subjects assigned to the Social Security scenario. All regressions control for age, gender, race, household income and education.

$* \mathrm{p}<0.10,{ }^{* *} \mathrm{p}<0.05, * * * \mathrm{p}<0.010$ 